\title{
Efisiensi dan Efektifitas Partisipasi Anggaran pada SKPD DISPERPA Kabupaten Magelang
}

\author{
Lisnawati $^{1}$, Nuwun Priyono ${ }^{2}$ \\ ${ }^{1}$ Akuntansi, Fakultas Ekonomi, Universitas Tidar \\ e-mail : lisna5784@gmail.com \\ ${ }^{2}$ Akuntansi, Fakultas Ekonomi, Universitas Tidar \\ e-mail : nuwunpriyono@untidar.ac.id
}

\begin{abstract}
This study aims to analyze the effectiveness and efficiency of the implementation of the expenditure budget Dinas Pertanian dan Pangan Kabupaten Magelang. This research uses qualitative research by using a descriptive approach. The level and effectiveness criteria of the implementation of the expenditure budget in the Dinas Pertanian dan Pangan Kabupaten Magelang in 2016-2019 varied greatly, the highest level of effectiveness occurred in 2018 and the lowest in 2016. The implementation of the budget for 2017, 2018 and 2019 was said to be effective, but in 2016 the level of effectiveness is still very lacking because the realization of the budget has a difference that is still very far from the target budget. This difference occurs because of a policy in 2016 that Dinas Pertanian dan Pangan Kabupaten Magelang does not implement grants. Dinas Pertanian dan Pangan Kota Magelang assesses that when the programmed activities are realized and as expected, the activities are said to be effective. The implementation of the 2016-2019 Dinas Pertanian dan Pangan direct expenditure budget as a whole has been processed efficiently. The implementation of the direct expenditure budget for 2017-2019 is categorized as very efficient. Only in 2016 was considered quite efficient. Managing direct budget has met the efficiency requirements, namely the use of minimum funds to achieve maximum results.
\end{abstract}

Keywords: Budget, effectiveness, efficiency

\begin{abstract}
Abstrak
Penelitian ini bertujuan untuk menganalisis efektifitas dan efisiensi pelaksanaan anggaran belanja Dinas Pertanian dan Pangan Kabupaten Magelang. Penelitian ini menggunakan jenis penelitian kualitatif dengan menggunakan pendekatan deskriptif. Tingkat dan kriteria efektifitas pelaksanaan anggaran belanja pada Dinas Pertanian dan Pangan Kabupaten Magelang tahun 2016-2019 sangat bervariasi, Tingkat efektifitas tertinggi
\end{abstract}

Lisnawati - Efisiensi dan Efektifitas Partisipasi Anggaran pada SKPD DISPERPA 
terjadi pada tahun 2018 dan yang terendah pada tahun 2016. Pelaksanaan anggaran belanja tahun 2017, 2018 dan 2019 di katakan efektif, tetapi pada tahun 2016 tingkat efektifitasnya masih sangat kurang karena realisasi anggaran belanja memiliki perbedaan yang masih sangat jauh dengan target anggaran belanja. Perbedaan ini terjadi karena adanya kebijakan pada tahun 2016 bahwa Dinas tidak melaksanakan hibah. Dinas Pertanian dan Pangan Kabupaten Magelang menilai ketika kegiatan yang diprogramkan sudah terealisasi dan sesuai dengan yang diharapkan, maka kegiatan tersebut dikatakan efektif. Pelaksanaan anggaran belanja langsung Dinas Pertanian dan Pangan tahun 2016-2019 secara keseluruhan sudah diolah secara efisien. Pelaksanaan anggaran belanja langsung tahun 2017-2019 dikategorikan sangat efisien. Hanya pada tahun 2016 dikategorikan cukup efisien. Pengelolaan anggaran belanja langsung sudah memenuhi syarat efisiensi yaitu penggunaan dana yang minimum untuk mencapai hasil yang maksimum.

Kata kunci : Anggaran belanja, efektifitas, efisiensi

\section{PENDAHULUAN}

Pemerintah Daerah merupakan perundang-undangan yang berhubungan dengan kebijakan desentralisasi ekonomi dan otonomi daerah. Pelaksanaan Pemerintahan di Indonesia hingga saat ini dianggap masih belum memberikan hasil yang baik dan menggembirakan dalam persoalan kemajuan tingkat ekonomi, kualitas sumberdaya manusia dan kekayaan sumber alam. Kemampuan Pemerintah Daerah dalam mengelola keuangan termuat dalam Anggaran Pendapatan dan Belanja Daerah (APBD) yang menggambarkan pelaksanaan tugas pembangunan yang dituntut untuk membangun ukuran kinerja yang baik. Ukuran kinerja yang disusun tidak dapat hanya dengan menggunakan suatu ukuran perlu ukuran yang berbeda untuk tujuan yang berbeda. Menurut (Matthews, 2011) Kinerja dapat diukur melalui efektifitasnya dari suatu kegiatan. Penyusunan Anggaran Pendapatan dan Belanja Daerah (APBD) yang memuat Rencana Kerja Anggaran (RKA) yang biasa disebut RKA SKPD. Dalam RKA SKPD telah memuat indikator kinerja yang akan dicapai untuk setiap program dan kegiatan yang akan dilaksanakan. Dalam RKA telah memuat input, output, dan outcome dari masingmasing program dan kegiatan. Jadi dalam RKA telah memuat sasaran anggaran. 
Efisiensi dan efektifitas dapat melihat suatu keadaan keuangan yang mempergunakan atau memanfaatkan sumber-sumber daya yang ada secara ekonomis, hemat (efisiensi) dan dilakukan secara tepat dan memenuhi sasaran (efektif) serta hasil yang dicapai tersebut memiliki rasionalitas terhadap penggunaan sumber-sumber yang ada (produktivitas). Efisiensi (daya guna) merupakan perbandingan antara output dengan input (Endah, 2015) Organisasi akan dinilai baik jika dalam melaksanakan tugas dapat mencapai tujuan yang telah ditetapkan pada standar yang tinggi dan biaya yang rendah. Tuntutan baru yang akan selalu memperhatikan value for money, karena tujuan yang selalu dikehendaki masyarakat selalu mencakup pertanggungjawaban mengenai pelaksanaanya, yaitu dalam pengadaan dan alokasi sumberdaya dalam arti penggunaanya diminimalkan dan hasil dimaksimalkan.

Anggaran Pemerintah terkait dengan jumlah penentuan alokasi dana untuk tiap-tiap kegiatan dalam suatu moneter yang menggunakan dana milik masyarakat. Anggaran Publik merupakan alat perencanaan yang harus di capai oleh pemerintah sedangkan anggaran sebagai alat pengendalian mengindikasikan alokasi sumber dana publik yang di setujui legislatif untuk di belanjakan melalui data rekening belanja yang terdapat dalam anggaran pendapat belanja pemerintah, akan dilihat apakah anggaran yang di buat akan berperan sebagai pengendali terhadap pelaksanaan kegiatan pemerintah. Tuntutan baru muncul agar Organisasi Sektor Publik memperhatikan value for money dalam menjalankan aktivitasnya. Menurut Sumenge (2013) Tujuan yang dikehendaki masyarakat mencakup pertanggungjawaban mengenai pelaksanaan value for money, yaitu ekonomis dalam mengadakan dan alokasi sumberdaya, efisien (berdaya guna) dalam penggunaan sumberdaya dalam arti penggunaanya di minimalkan dan hasilnya di maksimalkan, serta efektif dalam arti mencapai tujuan dan sasaran.

\section{METODELOGI PENELITIAN}

Jenis Penelitian yang digunakan dalam penelitian ini tentang analisis realisasi anggaran untuk menilai efektifitas dan efisiensi kinerja pemerintah di DISPERPA 
Kabupaten Magelang. Menggunakan penelitian kualitatif dengan pendekatan deskriptif yang mendeskripsikan data apa adanya dan menjelaskan data dengan kalimat penjelas secara kualitatif.

Tempat dilakukanya penelitian adalah Dinas Pertanian dan Pangan Kabupaten Magelang yang beralamat di Jl. Letnan Tukiyat, Kota Mungkid, Magelang 56511. Pengumpulan data penelitian pada DISPERPA Kabupaten Magelang di mulai pada tanggal 13 Januari 2020 sampai 13 Februari 2020

Prosedur penelitian merupakan langkah-langkah atau urutan yang harus dilalui atau dikerjakan dalam suatu penelitian. Menurut Chandrarin (2017) Prosedur penelitian yang harus di lakukan peneliti adalah sebagai berikut :

1. Melakukan studi kepustakaan (study pendahuluan)

2. Merumuskan masalah

3. Menentukan objek penelitian

4. Mengumpulkan data yang berupa Laporan Realisasi Anggaran Dinas Pertanian dan Pangan Kabupaten Magelang

5. Mengolah dan menyajikan data

6. Menganalisis data dengan cara menghitung efisiensi dan efektifitas pelaksanaan Laporan Realisasi Anggaran di Dinas Pertanian dan Pangan Kabupaten Magelang

7. Membuat kesimpulan dan saran sehingga dapat menjadi masukan untuk Dinas Pertanian dan Pangan Kabupaten Magelang.

Metode pengumpulan data yang digunakan adalah analisis data deskriptif kualitatif. Menurut Chandrarin (2017) Data kualitatif adalah data yang disajikan secara deskriptif atau data yang berbentuk uraian. Data ini bersumber dari Dokumen Realisasi Anggaran Belanja DISPERPA Kabupaten Magelang.

Analisis data yang digunakan adalah secara deskriptif kualitatif. Menurut Chandrarin (2017) analisis data deskriptif kualitatif yaitu dengan cara mengumpulkan data, disusun, dianalisis sehingga memberikan kesimpulan yang jelas dan objektif terhadap masalah yang ada yaitu mengenai segi efisiensi dan efektifitas Laporan Realisasi Anggaran DISPERPA Kabupaten Magelang. 


\section{Perhitungan Tingkat Efektifitas}

Menurut (Mohammad Mahsun, 2009) Tingkat efektivitas pelaksanaan Anggaran Belanja di DISPERPA Kabupaten Magelang, maka digunakan rumus :

$$
\text { Efektifitas }=\frac{\text { Realisasi Anggaran Belanja }}{\text { Target Anggaran Belanja }} \times 100 \%
$$

\section{Perhitungan Tingkat Efisiensi}

Menurut (Mohammad Mahsun, 2009) Tingkat Efisiensi pengukuran pencapaian output yang maksimum dengan penggunaan sumberdaya dan dana yang serendah rendahnya, Maka digunakan rumus sebagai berikut :

$$
\text { Efisiensi }=\frac{\text { Realisasi Anggaran Belanja Langsung }}{\text { Target Anggaran Belanja }} \times 100 \%
$$

\section{HASIL DAN PEMBAHASAN}

Analisis tingkat efektifitas anggaran belanja, tabel dibawah ini merupakan realisasi anggaran belanja di DISPERPA Kabupaten Magelang :

Tabel 1.Realisasi Anggaran Belanja DISPERPA Kabupaten Magelang Tahun 2016-2019

\begin{tabular}{ccc}
\hline Tahun & Target Anggaran & Realisasi \\
\hline $\mathbf{2 0 1 6}$ & 21.831 .713 .548 & 3.446 .352 .852 \\
\hline $\mathbf{2 0 1 7}$ & 28.400 .013 .498 & 20.595 .340 .451 \\
\hline $\mathbf{2 0 1 8}$ & 22.624 .432 .000 & 19.389 .046 .642 \\
\hline $\mathbf{2 0 1 9}$ & 16.774 .876 .861 & 12.368 .872 .469
\end{tabular}

Sumber : Dinas Pertanian dan Pangan Kabupaten Magelang (tahun 2016-2019)

Jumlah Belanja pada DISPERPA Kabupaten Magelang baik yang sudah ditargetkan maupun yang di realisasikan mengalami penurunan pada tahun 2016 yaitu target anggaran sebesar Rp 21.831.713.548 dan yang terpenuhi sejumlah Rp 
3.446.352.852. Kemudian di tahun 2017 mengalami peningkatan yang dianggarkan yaitu target anggaran sebesar Rp 28.400.013.498 dan yang terealisasikan sebesar Rp 20.595.340.451. Pada tahun 2018 mengalami penurunan yang dianggarkan yaitu target anggaran Rp 22.624.432.000 dan yang terealisasi Rp 19.389.046.642. Kemudian ditahun 2019 terjadi lagi penurunan yaitu target anggaran yang di anggarkan sebesar Rp 16.774.876.861 dan yang terpenuhi sejumlah Rp 12.368.872.469. Untuk dapat mengetauhi tingkat efektifitas dengan rumus sebagai berikut :

$$
\text { Efektifitas }=\frac{\text { Realisasi Anggaran Belanja }}{\text { Target Anggaran Belanja }} \times 100 \%
$$

Menurut Mahsun (2009) Standar ukuran efektifitas sesuai Acuan Litbang Depdagri (1991), kriteria tingkat efektifitas anggaran belanja sebagai berikut : Jika hasil perbandingan lebih dari 100\%, sangat efektif , 90\% - 100\%, dikatakan efektif , 90\% - 80\% dikatakan cukup efektif, 60\% - 80\% dikatakan kurang efektif dan jika dibawah 60\% dikatakan tidak efektif

Tabel 2. Realisasi Anggaran Belanja Langsung dan Total Realisasi Anggaran Belanja DISPERPA Kabupaten Magelang

\begin{tabular}{ccc}
\hline Tahun & Realisasi Belanja Langsung (Rp) & Realisasi Belanja (Rp) \\
\hline $\mathbf{2 0 1 6}$ & 29.070 .213 .548 & 3.446 .352 .852 \\
\hline $\mathbf{2 0 1 7}$ & 41.490 .013 .498 & 20.595 .340 .451 \\
\hline $\mathbf{2 0 1 8}$ & 25.524 .432 .000 & 19.389 .046 .642 \\
\hline $\mathbf{2 0 1 9}$ & 29.354 .876 .861 & 12.368 .872 .469
\end{tabular}

Sumber : Laporan Realisasi Anggaran Dinas Pertanian dan Pangan Kabupaten Magelang (tahun 2016-2019)

Jumlah Belanja langsung pada DISPERPA Kabupaten Magelang baik yang sudah ditargetkan maupun yang di realisasikan mengalami penurunan pada tahun 2016 yaitu realisasi belanja langsung sejumlah $\mathrm{Rp} 29.070 .213 .548$ dan yang terealisasi sejumlah $\mathrm{Rp}$ 3.446.352. Kemudian di tahun 2017 mengalami peningkatan realisasi belanja langsung sejumlah $\mathrm{Rp} 41.490 .013 .498$ dan yang terealisasi sebesar Rp 20.595.340.451. Pada tahun 2018 mengalami penurunan 
realisasi belanja langsung sejumlah $\mathrm{Rp}$ 25.524.432.000 dan yang terealisasi sejumlah Rp 19.389.046.642, terakhir pada tahun 2019 mengalami peningkatan pada realisasi belanja langsung sejumlah Rp 29.354.876.861 dan yang terealisasi sejumlah Rp 12.368.872.469. Untuk dapat mengetauhi tingkat efisiensi dapat menggunakan rumus sebagai berikut :

$$
\text { Efisiensi }=\frac{\text { Realisasi Anggaran Belanja Langsung }}{\text { Target Anggaran Belanja }} \times 100 \%
$$

Menurut Mahsun (2009) Standar ukuran efisiensi sesuai Acuan Litbang Depdagri (1991), mengenai tingkat kriteria efisiensi anggaran belanja adalah sebagai berikut : Jika hasil perbandingan melebihi 100\% maka anggaran tidak efisien, 90\% - 100\% kurang, 80\%-90\% cukup, 60\%-80\% efisien dan jika dibawah $60 \%$ dikatakan sangat efisien.

1. Analisis Tingkat Efektifitas Anggaran Belanja di Dinas Pertanian dan Pangan Kabupaten Magelang

Berikut disajikan tabel yang menggambarkan Tingkat Efektifitas Pelaksanaan Anggaran Belanja DISPERPA Kabupaten Magelang

Tabel 3. Tingkat Efektifitas Pelaksanaan Anggaran Belanja DISPERPA Kabupaten Magelang

\begin{tabular}{ccccc}
\hline Tahun & Target (Rp) & Realisasi (Rp) & Tingkat Efektifitas (\%) & Kriteria \\
\hline $\mathbf{2 0 1 6}$ & 21.831 .713 .548 & 3.446 .352 .852 & $15,78 \%$ & Tidak Efektif \\
\hline $\mathbf{2 0 1 7}$ & 28.400 .013 .498 & 20.595 .340 .451 & $72,51 \%$ & Kurang Efektif \\
\hline $\mathbf{2 0 1 8}$ & 22.624 .432 .000 & 19.389 .046 .642 & $85.69 \%$ & Cukup Efektif \\
\hline $\mathbf{2 0 1 9}$ & 16.774 .876 .861 & 12.368 .872 .469 & $73,75 \%$ & Kurang efektif
\end{tabular}

Sumber : Laporan realisasi anggaran Dinas Pertanian dan Pangan Kabupaten Magelang (Data olahan tahun 2016-2019)

Tabel di atas menujukkan tingkat efektifitas dari anggaran belanja DISPERPA Kabupaten Magelang selama periode tahun anggaran 2016-2019, tingkat efektifitas anggaran belanja berubah ubah dari tahun ke tahun, kadang mengalami penurunan dan kadang pula mengalami peningkatan. Pada tahun 2016 tingkat efektifitas sebesar $15.78 \%$ dan mengalami peningkatan di tahun 
2017 sebesar $56.73 \%$ menjadi $72.51 \%$. Setelah itu mengalami peningkatan yang cukup besar kembali di tahun 2018 yaitu sebesar 13.18\% menjadi 85.69\%. Dan pada tahun 2019 mengalami penurunan yang cukup drastis yaitu sebesar 11.94\% menjadi 73.75\%. Secara keseluruhan dari tahun 2016-2019 tingkat efektifitas anggaran belanja DISPERPA Kabupaten Magelang memiliki tren yang berubah-ubah, kadang mengalami peningkatan kadang pula mengalami penurunan.

2. Analisis Tingkat Efisiensi Anggaran Belanja Langsung DISPERPA Kabupaten Magelang

Berikut disajikan tabel yang menggambarkan tingkat efisiensi anggaran belanja langsung dari tahun 2016-2019 pada DISPERPA Kabupaten Magelang

Tabel 4. Tingkat Efisiensi Pelaksanaan Anggaran Belanja Langsung Dinas Pertanian dan Pangan Kabupaten Magelang

\begin{tabular}{ccccc}
\hline Tahun & $\begin{array}{c}\text { Realisasi Belanja } \\
\text { Langsung (Rp) }\end{array}$ & $\begin{array}{c}\text { Realisasi Belanja } \\
\text { (Rp) }\end{array}$ & $\begin{array}{c}\text { Tingkat } \\
\text { efisiensi (\%) }\end{array}$ & Kriteria \\
\hline $\mathbf{2 0 1 6}$ & 29.070 .213 .548 & 3.446 .352 .852 & $83,86 \%$ & Cukup efisien \\
\hline $\mathbf{2 0 1 7}$ & 41.490 .013 .498 & 20.595 .340 .451 & $20.14 \%$ & Sangat efisien \\
\hline $\mathbf{2 0 1 8}$ & 25.524 .432 .000 & 19.389 .046 .642 & $13,16 \%$ & Sangat efisien \\
\hline $\mathbf{2 0 1 9}$ & 29.354 .876 .861 & 12.368 .872 .469 & $27,73 \%$ & Sangat efisien
\end{tabular}

Sumber : Laporan realisasi anggaran belanja langsung Dinas Pertanian dan Pangan Kabupaten Magelang (Data olahan tahun 2016-2019)

Tabel di atas menunjukkan tingkat efisiensi dari anggaran belanja langsung DISPERPA Kabupaten Magelang selama periode 2016-2019. Pada tahun 2016 tingkat efisiensi sebesar $83,86 \%$ menjadi $20,14 \%$ pada tahun 2017. Dari sudut pandang efisiensi perubahan ini di pandang sebagai peningkatan efisiensi namun masih dalam kriteria yang sangat efisien. Pada tahun 2018 mengalami kenaikan tingkat efisiensi yang cukup besar sebesar 6.98\% menjadi 13,16\% dan memiliki kriteria sangat efisien. Pada tahun 2019 kembali mengalami peningkatan tingkat efisiensi yang sangat drastis sebesar $14,57 \%$ menjadi $27,73 \%$ dan masih dalam kriteria yang sangat efisien. Secara keseluruhan 
anggaran belanja langsung DISPERPA Kabupaten Magelang tahun 2016-2019 sudah efisien dengan tingkat efisien di bawah 60\% pada tahun 2017-2019 yang masuk pada kriteria sangat efisien. Dan hanya pada tahun 2016 tingkat efisiensi berada di sekitaran 80\%-90\% yang memiliki kriteria yang cukup efisien.

\section{KESIMPULAN}

Berdasarkan hasil penelitian yang dilakukan, maka dapat disimpulkan bahwa Tingkat dan kriteria efektifitas anggaran belanja DISPERPA Kabupaten Magelang tahun 2016-2019 sangat bervariasi. Tingkat efektifitas tertinggi terjadi pada tahun 2018 dan yang terendah terjadi pada tahun 2016. Anggaran belanja tahun 2016, 2017, 2018, dan 2019 sudah bisa dikatakan efektif, Menurut Anik Purnamasari SP.MMA selaku Staff Bendahara Pengeluaran di DISPERPA Kabupaten Magelang pada tahun 2016 tingkat efektifitasnya masih sangat kurang karena realisasi anggaran belanja masih sangat jauh dengan target anggaran belanja yang harus dicapai. Hal ini terjadi karena adanya kebijakan bahwa pada tahun 2016 jika hibah tidak boleh dilaksanakan karena adanya masalah yang tidak bisa diungkapkan. Tetapi untuk kegiatan yang lain yang telah di anggarkan, kegiatan sudah di laksanakan secara efektif. DISPERPA Kabupaten Magelang menilai, ketika kegiatan yang sudah di programkan sudah terealisasi dan sesuai yang diharapkan, maka kegiatan tersebut dikatakan efektif.

Anggaran belanja langsung DISPERPA Kabupaten Magelang tahun 2016-2019 secara keseluruan sudah diolah secara efisien. Dimana anggaran belanja langsung tahun 2017-2019 sangat efisien, tahun 2016 cukup. Pengelolaan angggran telah terpenuhi yaitu penggunaan dana yang minimum untuk mencapai hasil yang maksimum.

\section{DAFTAR RUJUKAN}

Agustina, 0. (2013). Analisis Kinerja Keuangan Daerah dan Tingkat Kemandirian Daerah di Era Otonomi Daerah: Study Kasus Kota Malang (Tahun Anggaran 2007-2011). . http:/jimfeb.ub.ac.id.

Aril, S. (2013). Analisis Efektifitas dan Efisiensi Pelaksanaan Anggaran Belanja Badan Perencanaan Pemabnagunan Daerah (BAPPEDA) . Minahasa Selatan Jurnal Akuntansi dan Manajemen , Vol 1 No 3 ISSN 2303-1174 Hal 74-81 . 
Chandrarin, G. (2017). Metode Riset Akuntansi Pendekatan Kuantitatif . Penerbit Salemba Empat.

Cicilia, E. V. (2015). Analisis Efisiensi dan Efektivitas Serta Kemandirian Pengelolaan Keuangan Daerah Di Kabupaten Minahasa Utara. . Jurnal Pembangunan Ekonomi dan Keuangan Daerah.

Depdagri, A. L. (1991). Standar Ukuran Efektifitas Anggran Belanja .

K. G. (2014). Budgeting Efficiency for Cost Control Purposein Management Accounting System . Kazan State University Rusia.

Mahsun, M. (2009). Pengukuran Kinerja Sektor Publik . BPFE Yogyakarta .

Mandey, R. K. (2015). Analisis Kinerja Pendapatan Asli Daerah Dikaitkan Dengan Belanja Daerah Pada Pemerintah Kota Bitung. Jurnal EMBA. .

Mardiasmo, A. (2009). 2009. Akuntansi Sektor Publik.

Mathewa, J. R. (2011). Assesing Organization Effectiveness, The Role Of Performanca Meansure, . The University Of Chicago , Libarary Quartely Vol 81 No 1.

Pontoh, W. ( 2013). Akuntansi: Konsep dan Aplikasi. Halaman Moeka, Jakarta Barat.

Sugiyono. (2010). Metode Penelitian Pendidikan Pendekatan Kuantitatif Kualitatif. Bandung, Alfabeta.

Sujarweni, V. W. (2015). Akuntansi Sektor Publik . Pustaka Baru Press, Yogyakarta .

Sumenge, A. (September 2013). Analisis Efektivitas dan Efisiensi Pelaksanaan Anggaran Belanja Badan Perencanaan Pembangunan Daerah (BAPPEDA) Minahasa Selatan. Jurnal Akuntansi dan Manajemen. Vol. 1 No.3 ISSN 23031174, Hal. 74-81. 